\title{
IAMJ
}

INTERNATIONAL

AYURVEDIC

MEDICAL JOURNAL

\section{A PHARMACOGNOSTICAL STUDY ON THE STEM BARK OF DEVADARU (CedruS deodara Roxb. Loud.G.Don)}

\author{
Amrita Sharma ${ }^{1}$, Chander Shekhar Sharma ${ }^{2}$ \\ ${ }^{1}$ Ex. Assistant Professor, P.G Department of Dravyaguna, Dayanand Ayurvedic College, Jalandhar, Punjab, India \\ ${ }^{2}$ Professor \& Head, Department of Kayachikitsa, Dayanand Ayurvedic College, Jalandhar, Punjab, India
}

Corresponding Author:shekhars76@gmail.com

\section{https://doi.org/10.46607/iamj0909022021}

(Published online: February 2021)

Open Access

(C) International Ayurvedic Medical Journal, India 2021

Article Received:31/01/2021 - Peer Reviewed:06/02/2021 - Accepted for Publication:08/02/2021

Check for updates

\begin{abstract}
Ayurveda is the ancient knowledge of scientific system of Indian medicine. This medicinal system incorporates the use of Dravyas - medicinal plants, which proved to be an effective means of human care in the pre and post Vedic periods. One among many such plants is Devadaru. Etymologically the word 'Devadaru' itself personify the plant as 'Devta' or divine tree, because it provides environment with solitude and its medicinal values. To explore more about Devadaru pharmacognostical study of stem bark was conducted. To authenticate the sample of Devadaru, comparison of organoleptic characteristics of stem bark and its powder was done which reveals that stem bark has some aromatic compounds. Based on organoleptic characteristics obtained and microscopic observations, genuineness of the raw material was authenticated. The microscopic study of cut sections and powder of stem bark was done. The observations could be considered to be the reference standards in future studies and will be of immense help in standardization of Ayurvedic medicines to meet the international parameters.
\end{abstract}

Keywords: Devadaru, Cedrus deodara, Pharmacognostical, Stem bark. 


\section{INTRODUCTION}

Since time immemorial the crucial authority of herbal medicine in serving the therapeutic requirements of the population worldwide needs no evidence. Nearly $80 \%$ of the global population still depends upon the herbal drugs for their health care ${ }^{1}$. However, a key factor responsible for its acceptability in developed countries is the lack of documentation. A necessity is always felt for the evidence-based research studies to be carried out on traditional systems of medicine. For error-free identification, authentication, and standardization, pharmacognosy is important and necessary. Keeping this in mind, it becomes exceptionally important to evolve the quality of plant-based medicines. The authenticity of drugs to prevent their exploitation and adulteration, documentation and stringer quality control, researching and discovering the availability of medicinal ingredients in the different parts of the plants is the need of the hour so as to have more ingredients per plant to reduce the use and removal of large number of plants. For evaluating the therapeutic potential of the drugs, official standards are necessary to control the quality and safety of drugs using proper modern scientific techniques ${ }^{2}$. To meet the above referred standards for herbal medicine, quality evaluation of stem bark of the trial drug Devadaru (Cedrus deodara.Roxb.) was done on the Pharmacognostical and Physicochemical basis.

Material and Methods:

The detailed pharmacognostical evaluation will give valuable information regarding the morphology, microscopic, physical characteristics and phyto-chemical evaluation of crude drugs ${ }^{3}$.In the present study the stem bark of Devadaru (Cedrus deodara Roxb.Loud) has been evaluated pharmacognosticaly with following aims and objectives:

\section{Aim and Objectives}

1. To evaluate the macroscopic characters of stem bark of Cedrus deodara Roxb.Loud and its powder by organoleptic methods.

2. To study microscopic characters of stem bark of Cedrus deodara Roxb.Loud.
3. To study powder microscopy of stem bark of Cedrus deodara Roxb.Loud.

\section{Materials and Methods}

A) Material: The stem bark of a fully developed Devadaru tree (Cedrus deodara Roxb.Loud).

\section{B) Collection of samples}

The selected samples of stem bark of Devadaru tree were collected from their native habitatfrom the forest range of Mcleodganj /Dharamshala, district Kangra (Himachal Pradesh) and based on the Ayurvedic Pharmacopoeia of India (API), the samples were botanically verified and confirmed by expert at D.T.L, R.I.I.H.S Jogindernagar, Distt. Mandi (Himachal Pradesh).

\section{C) Processing and Preservation of sample}

The collected sample of stem bark of Devadaru was sorted out for foreign matter, washed properly and dried in shade. After drying, a small part of a sample was preserved in its natural form and some part of the samples was finely powdered in disintegrator and then sieved in 80 mesh sieves. It was then packed and stored in airtight containers till further use.

\section{D) Pharmacognostical Study}

The pharmacognostical study of the sample for macroscopic and microscopic characters was carried outat Department of Pharmacognosy at I.S.F. College of pharmacy, Moga (Punjab.)

\section{Macroscopic study}

The cut sections of samples of stem bark of Devadaru were spread on clean dry plastic sheets and were separately investigated for different organoleptic features by using sense organs. Colour, odour, taste and texture, size, shape, fracture, surface were noted.The samples of stem bark of Devadaru were pulverized to coarse powder and sieved through mesh no. 40, which were then spread on a clean dry plastic sheets and were separately investigated for different organoleptic features by using sense organs. Colour, odour, taste and texture, size, shape, fracture, surface were noted ${ }^{4,5}$ 


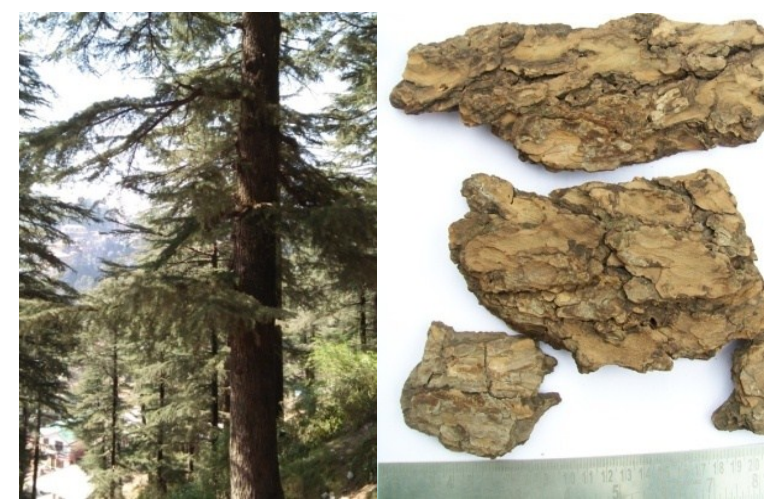

Fig.1 The Deodar Tree Fig. 2 The stem bark

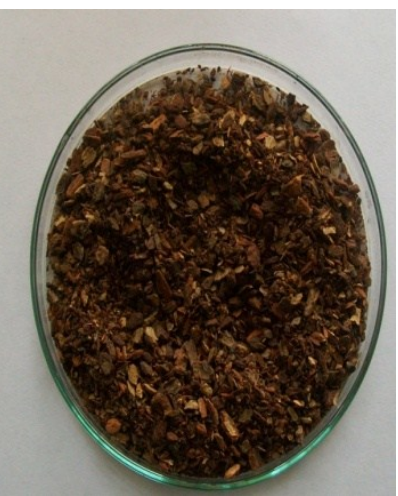

Fig. 3 Coarse powder

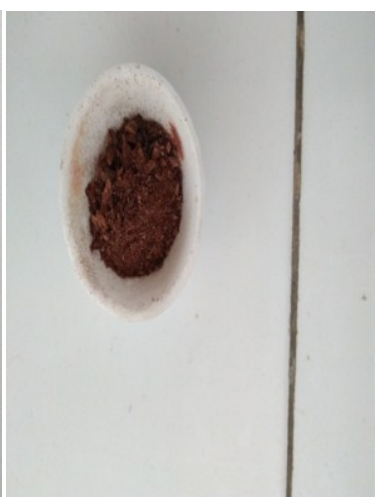

Fig.4 Fine powder

\section{Microscopic study}

The study was done as follows:

Section cutting: The small pieces of stem bark were soaked in distilled water and sodium hydroxide solution for anatomical sections and standard microtomy techniques were followed. Transverse sections of 10 to $12 \mu \mathrm{m}$ thickness were prepared. The sections were stained with $0.5 \%$ safranin stain adjusted to neutral $\mathrm{pH}$. To study different anatomical features, slides were observed under motic images +2.0 trinocular photomicrograph and microscope photography was done ${ }^{6}$.

\section{a) Stem bark samples:}

Dried stem bark sample was soaked overnight in distilled water, sodium hydroxide and warm distilled water for 48 hours, then transverse sections as above mentioned were taken and photomicrography was done after proper staining and mounting.

\section{b) Powder microscopy}

The pieces of stem bark of Cedrus deodara were pulverized to coarse powder and sieved through mesh no. 40. A pinch of each powder was placed on a microscopic slide and mounted with phloroglucinol, hydrochloric acid and glycerine. The slides were observed under simple microscope and Motic images +2.0 trinocular photomicrograph unit ${ }^{7}$.

\section{Microchemical tests}

To detect starch grains and lignified elements microchemical tests of powder of stem bark of Devadaru were performed as follows ${ }^{4}$ :

\section{i) Test for starch grains:}

Powder ofstem bark was placed on microscopic slides. The slide was mounted with a drop of iodine solution and observed under microscope. Starch grains turned blue when examined microscopically. The results obtained were noted.

\section{ii) Test for the fibers (lignified elements):}

Powder of stem bark was placed on microscopic slides. The slides were treated with phloroglucinol and hydrochloric acid and observed under microscope. Lignified fibres turned pink in colour and results obtained were noted.

\section{Microscopic Study}

Transverse Section of Stem bark (Cedrus deodaraRoxb. Loud.)

Shows Cork cellsin 4-6 layers of tangentially elongated hexagon cells, with yellowish brown matter cork cells of light brown to yellowish brown in colour on the outer most layer of the bark. Resin duct of yellowish orange hue is seen between tracheids on the inner side of transverse section of the bark shows immature cells of tracheids.

Powder microscopy of the sample of stem bark of the Devadaru:

It shows the presence of

a) Lignified fibres-Thick heavily lignified with pointed ends.

b) Phelloderm- 6-8 layers of thin walled rectangular cells with starch grains.

c) Calcium oxalate crystals - Calcium oxalate crystals in prism, hexagonal shape. 


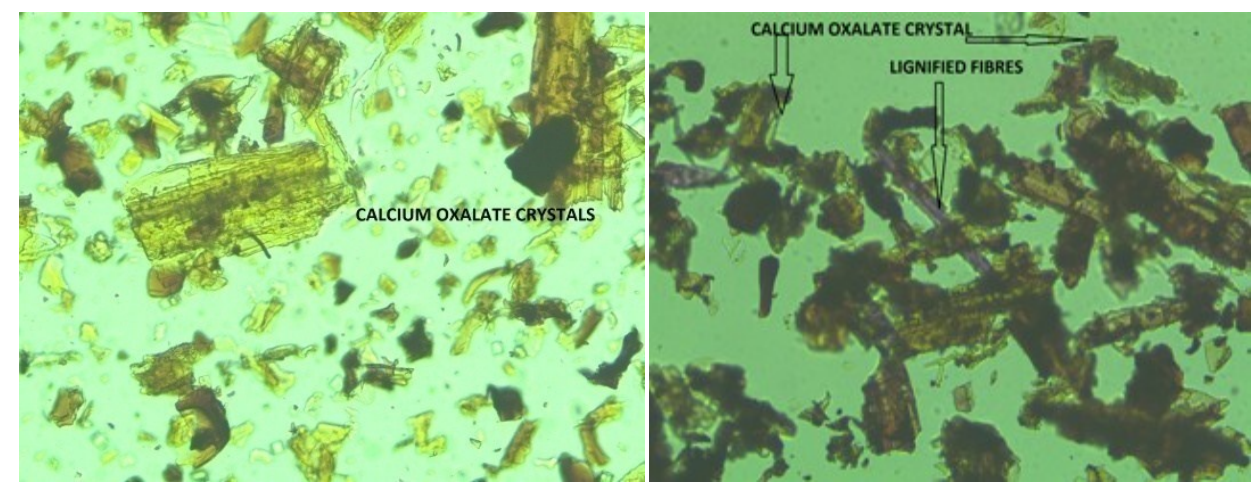

Fig. 5 Microscopic view of stem bark showing calcium oxalate crystals and lignified fibres

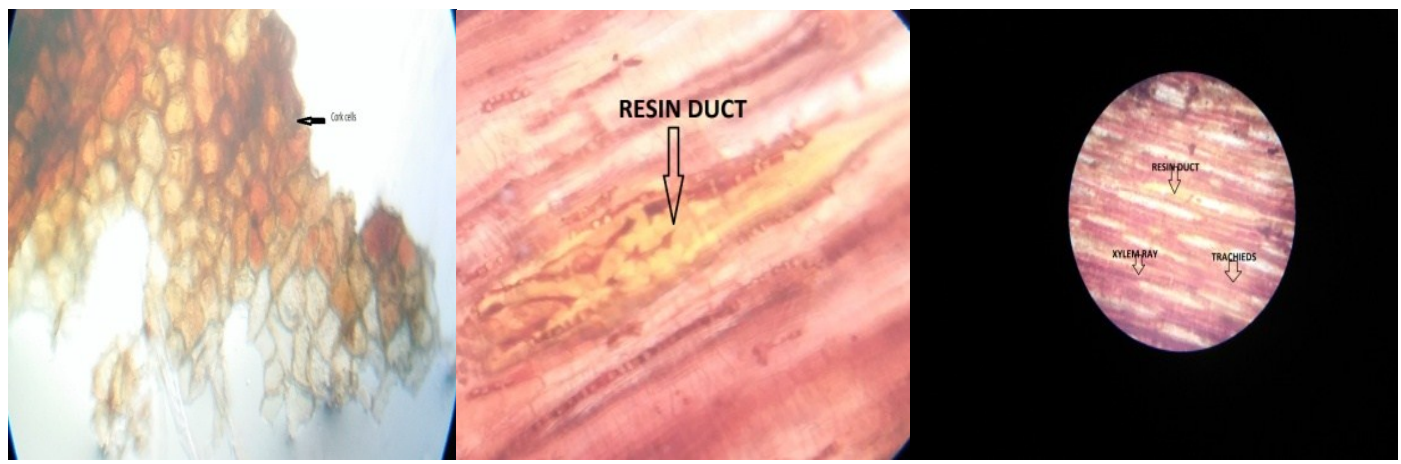

Fig.6 Outer layer of the bark showing cork cells Fig.7 Inner layer showing immature tracheid and resin ducts

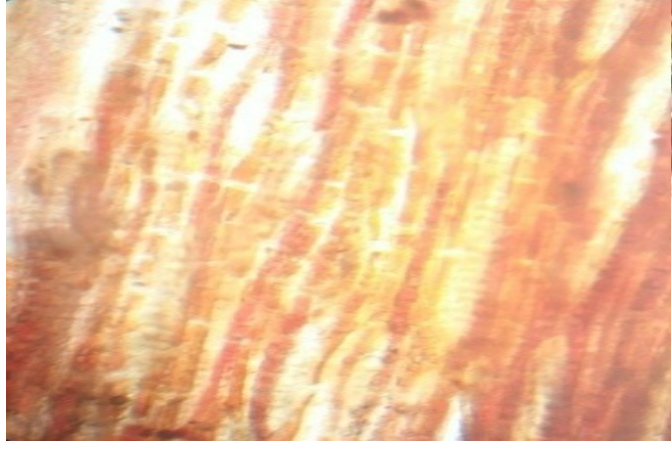

Fig. 8 Inner most layer of the bark

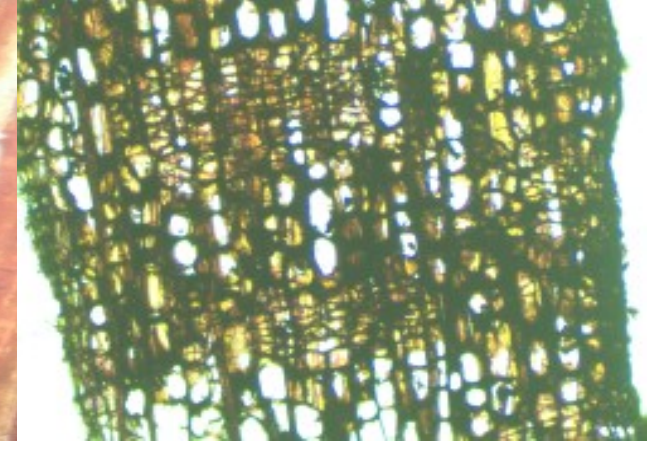

Fig. 9 Outer most layer of the bark

\section{Physicochemical analysis:}

Standardization and quality control of herbs is the process involved in the physicochemical evaluation of crude drug covering aspects, such as selection and handling of crude material, safety, efficacy and stability assessment of finished product. Thus, to prove its acceptability as a quality drug it is essential to analyse its physico-chemical parameters ${ }^{8,}$. . The physicochemical parameters of the stem bark of Cedrus deodara Roxb.Loud was determined as follows.

\section{Materials and Methods:}

The samples of stem bark of Devadaru were cleaned washed dried well and grinded to powder (80\#) has been used for this study. The following physicochemical parameters of the sample were analyzed ${ }^{10}$.

\section{a) Foreign matter}

Foreign matter in herbal drugs consists of either parts of the medicinal plant or it may be an organism, part or product other than that specified in the standard. This is usually referred to as Foreign Organic Matter (FOM).Foreign matter may consist of part of organ or 
organs from which the drug is derived or parts of other drugs, matter coming from other sources of contamination, moulds insects or other animal contamination. Also, foreign matter includes stones, soil, dust and other inorganic contaminants.

Procedure: Crude drug weighing 500gm was taken and spread out in thin layer. The sample was inspected with unaided eyes and with the lens of magnification $6 x$. The foreign matter was manually separated as much as possible. Weight after this cleaning is calculated. The net foreign matter was calculated from the following formula:

Weight of the sample after cleaning x 100

Weight of the sample before cleaning

The foreign matter was calculated for the stem bark.

\section{b) Loss on drying}

Procedure: Sample drug of weight $10 \mathrm{gm}$ was taken in a pre-weighed dried petri dish. It was dried in an oven at $105^{\circ} \mathrm{c}$ until reaching a constant weight. The petri dish was taken out, self-cooled and weighed immediately. The weight loss i.e. loss on drying was calculated and expressed as $\% \mathrm{w} / \mathrm{w}$.

\section{c) Ash Values}

The residue remaining after incineration of the plant material is the ash value, which simply represents inorganic salts naturally occurring in the crude drugs or adhering to it or deliberately added to it, as a form of adulteration.

\section{1) Total ash}

Total ash is the measure of the total amount of material left after burning. The total ash usually consists of carbonates, phosphates, silicates and silica which include both physiological ash derived from the plant tissue itself and non-physiological ash which are the residue of the extraneous matter like sand and soil particles to the plant surface.

Procedure: The $3 \mathrm{gm}$ of the drug was accurately weighed and taken in a pre-weighed silica crucible, previously dried and weighed. It was incinerated in muffle furnace at a temperature not exceeding $450^{\circ} \mathrm{c}$, then cooled and weighed. From the weight of the residue obtained the ash value was calculated on the basis of air-dried sample and expressed as \% w/w.

\section{2) Acid insoluble ash}

Acid insoluble ash is the residue obtained after boiling the total ash with dilute hydrochloric acid and igniting the remaining insoluble matter. This ensures the amount of silica present especially as sand and siliceous earth.

Procedure: The ash obtained from the ash value analysis was boiled for five minutes with $25 \mathrm{ml}$. of dilute $(6 \mathrm{~N})$ hydrochloric acid. The insoluble matter was collected on an ash less filter paper and washed with hot water (till litmus paper becomes neutral), then incinerate the filter paper with substratum in a hot air oven till complete dry to constant weight.

3) Water soluble ash: Water soluble ash is the difference in the weight between the total ash and the residue after treatment of total ash with water.

Procedure: The ash obtained from the ash value analysis was boiled for five minutes with $25 \mathrm{ml}$ of distilled water. The insoluble matter was collected on the ash less filter paper and washed with hot water (till litmus paper becomes neutral), then incinerate the filter paper with substratum in a hot air oven till complete dry to constant weight. The percentage of insoluble ash was calculated with reference to an air-dried sample.

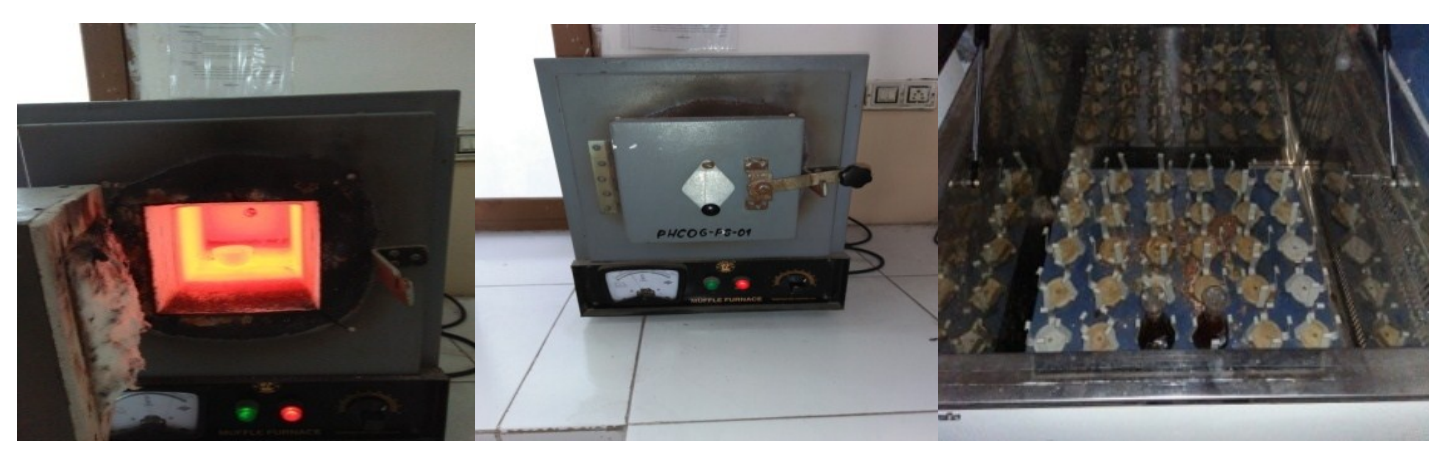


Fig.10 Physico- chemical analysis of stem bark

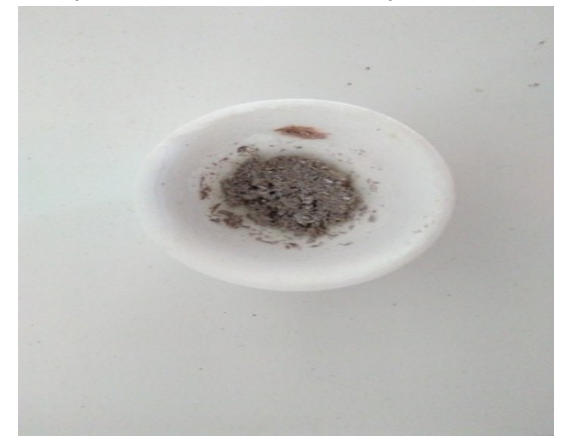

Fig. 11 Ash of stem bark

\section{d) Determination of Extractable Matter}

The extracts obtained by exhausting plant materials with specific solvents are indicative of approximate measures of their chemical constituents extracted with those solvents from a specific amount of air-dried material.

i) Water soluble extractive (WSE)

\section{Procedure:}

The Five gm of the sample was weighed accurately. To it $100 \mathrm{ml}$ of distilled water was added and (shook for 6 hrs. Retained for 18 hours) kept overnight. It was stirred intermittently in the initial period, next day it was filtered. A $25 \mathrm{ml}$ of the filtrate was accurately measured with pipette and transferred to the already weighed evaporating dish. The evaporating dish was placed on a water bath for evaporation of the water. After evaporation of the water it was dried in an oven, allowed cooling and weighed immediately. From the weight of the residue obtained the percentage of water-soluble extractive was calculated and expressed as $\% \mathrm{w} / \mathrm{w}$.

ii)Alcohol soluble extractive (ASE)

\section{Procedure:}

Five gm of the sample was weighed accurately. To it $100 \mathrm{ml}$ of ethyl alcohol was added and shook for $6 \mathrm{hrs}$. The same was retained for 18 hours. It was stirred intermittently in the initial period, next day it was filtered. A $25 \mathrm{ml}$ of the filtrate was accurately measured with pipette and transferred to the already weighed evaporating dish. The evaporating dish was placed on a water bath for evaporation of the alcohol. After evaporation of the alcohol (it was dried in an oven), allowed cooling and weighed immediately. From the weight of the residue obtained the percentage of alcohol soluble extractive was calculated and expressed as $\% \mathrm{w} / \mathrm{w}$.

\section{Foaming index:}

Determination of Foaming Index ${ }^{11}$

The foaming ability of an aqueous decoction of plant material and their extracts is measured in term of foaming index. $1 \mathrm{gm}$ each of powder drug was accurately weighed and transferred into $500 \mathrm{ml}$ flasks containing $100 \mathrm{ml}$ water and boiled for 30 minutes, cooled and filtered into $100 \mathrm{ml}$ volumetric flasks and made up the volume with water. Each decoction poured into 10 stopper test tubes in successive portion of $1 \mathrm{ml}, 2 \mathrm{ml}, 3 \mathrm{ml}, 4 \mathrm{ml}$, etc. up to $10 \mathrm{ml}$ and the volume of liquid in each test tube was adjusted with water to $10 \mathrm{ml}$ and shaken them in length wise motion for 15 seconds. Test tubes were allowed to stand for 15 minutes and the height of the foam was measured, and the results were assessed.

If the height of foam in every tube was less than $1 \mathrm{~cm}$, the foaming index was considered less than 100. If height of the foam was more than $1 \mathrm{~cm}$ in every test tube, the foaming index was over than 100. In such cases repetition was done using a new series of dilutions of decoction in order to obtain the results. If the height of foam in any test tube was $1 \mathrm{~cm}$, the volume of the plant material in that tube (a) was used for determination of index.

Formula for calculation of the Foaming

Index $=1000 / \mathrm{a}$

Where $\mathrm{a}=$ volume of decoction was used for preparing the dilution in tube where foaming height was $1 \mathrm{~cm}$ measured. 


\section{Determination of $\mathbf{p H}$}

The $\mathrm{pH}$ value of an aqueous liquid may be defined as the common logarithm of the reciprocal of the hydrogen ion concentration. The $\mathrm{pH}$ value conventionally represents the acidity or alkalinity of aqueous solution. $5 \% \mathrm{w} / \mathrm{w}$ aqueous solution of the samples was prepared, it was filtered, and $\mathrm{pH}$ of the filtrate was noted $25^{\circ} \mathrm{c}$.

\section{Observation and Results}

Based on the Pharmacognostical, Phytochemical study done of the sample of stem bark of $C$. deodara in the following observations were made and results were obtained.

\section{Observation:}

Organoleptic characters of obtained sample of stem bark of $C$. deodara and its powder on the basis of observations are given in table 1 and 2 respectively.

Table 1: Organoleptic characters of sample of stem bark of $C$. deodara.

\begin{tabular}{|l|l|l|}
\hline Sr. No. & Parameters & Results \\
\hline $\mathbf{1 .}$ & Texture & Rough \\
\hline $\mathbf{2 .}$ & Colour & Outer surface dark brown, inner surface brownish buff coloured. \\
\hline $\mathbf{3 .}$ & Odour & Slightly aromatic \\
\hline $\mathbf{4 .}$ & Taste & Bitter \\
\hline $\mathbf{5 .}$ & Shape & Irregular strips \\
\hline $\mathbf{6 .}$ & Size & $14-15 \mathrm{c} . \mathrm{m}$ long and $5-6 \mathrm{~cm}$ wide and $1.5-2 \mathrm{~cm}$ thick. \\
\hline $\mathbf{7 .}$ & Fracture & Short, fibrous, splintery fracture. \\
\hline $\mathbf{8 .}$ & Surface & Coarse and uneven with striations and furrows. \\
\hline
\end{tabular}

Table 2: Organoleptic characters of sample of stem bark powder of C. deodara.

\begin{tabular}{|l|l|l|}
\hline Sr. No. & Parameters & Results \\
\hline 1. & Texture & Dry Fine powder \\
\hline 2. & Colour & Dark brown \\
\hline 3. & Odour & Faint \\
\hline 4. & Taste & Bitter \\
\hline
\end{tabular}

The observations and result of the micro-chemical tests performed on the powder of stem bark of C.deodara are summarized in table 3 and 4.

Table 3: Result of Microchemical observations on sample of stem bark powder of $C$. deodara.

\begin{tabular}{|l|l|l|l|}
\hline S.No. & Test & Observation & Characteristics \\
\hline 1. & Powder + Iodine solution & Blue & Starch grains \\
\hline 2. & Powder + Phloroglucinol $+\mathrm{HCl}$ & Pink & Lignified fibres \\
\hline
\end{tabular}

Table 4: Physico-chemical analysis of stem bark sample of C.deodara.

\begin{tabular}{|c|c|c|c|}
\hline $\begin{array}{l}\text { Sr. } \\
\text { No. }\end{array}$ & $\begin{array}{l}\text { Physicochemical } \\
\text { Parameters }\end{array}$ & $\begin{array}{l}\text { Values obtained } \\
(\% \mathrm{w} / \mathrm{w})\end{array}$ & $\begin{array}{l}\text { Reported values } \\
(\% \mathrm{w} / \mathrm{w})\end{array}$ \\
\hline 1. & Foreign matter & 0.96 & - \\
\hline 2. & Loss on drying & $13.2 \pm 0.02$ & $12 *$ \\
\hline 3. & Total ash & $4.6 \pm 0.03$ & $5.6^{*}$ \\
\hline 4. & Water soluble ash & $1.4 \pm 0.09$ & - \\
\hline 4. & Acid insoluble ash & $1.3 \pm 0.08$ & $.93 *$ \\
\hline 5. & Water soluble extractive & $5.6 \pm 0.09$ & $9.6^{*}$ \\
\hline 6. & Alcohol soluble extractive & $8.8 \pm 0.4$ & $8.8^{*}$ \\
\hline
\end{tabular}

Values \pm S.E.M, $n=3$ 
Table 5: Foaming index of stem bark of $C$. deodara.

\begin{tabular}{|l|l|l|}
\hline S. No. & Samples & Height of foam \\
\hline 1. & Stem bark & $<1 \mathrm{~cm}$ \\
\hline
\end{tabular}

Result shows presence of saponins.

Table 6: $\mathrm{pH}$ value of stem bark of $C$. deodara.

\begin{tabular}{|l|l|l|}
\hline S. No. & Sample & pH value \\
\hline 1. & Stem bark & 5.2 \\
\hline
\end{tabular}

\section{DISCUSSION}

In the present study of the stem bark of Devadaru, the organoleptic characteristics of stem bark was found to be rough, dark brown buff, slightly aromatic, bitter, irregular strips, short splintery and coarse uneven with striations and furrows. The organoleptic characters of the powder of stem bark shows as dry fine powder, dark brown, faint and bitter in taste. These observations show that stem bark has some aromatic compounds. The section cutting of stem bark showed cork cells in 4-6 layers of tangentially elongated hexagon cells, with yellowish brown matter cork cells of light brown to yellowish brown in colour on the outer most layer of the bark. Resin duct of yellowish orange hue is seen around immature tracheids. However, the powder microscopy of the stem bark shows presence of calcium oxalate crystals, cork cells, resin duct in immature bark, while the microchemical tests showed the presence of lignified fibres. In physico-chemical study, the loss on drying of any sample is directly related to its moisture content. If the moisture content is high, then it can cause decomposition of the crude drug either due to chemical change or microbial contamination. Hence, loss on drying of the sample was found to be $13.2 \pm 0.02 \%$ for stem bark. The residue remaining after incineration is the ash content of the drug, which simply represents inorganic salts, naturally occurring in drug or adhering to it or deliberately added to it, as a form of adulteration. Ash value was found to be $4.6 \pm 0.03 \%$ for the stem bark. Adhering dirt and sand (silica) as determined by acid insoluble ash content was found to be $1.3 \pm 0.08 \%$ for stem bark. Water soluble and alcohol soluble extractive values are indicative of the bioavailability of the plant compounds in the extracts. Values obtained for W.S.E and
A.S.E were $5.6 \pm 0.09 \%$ and $8.8 \pm 0.04 \%$ respectively for stem bark. These values reveal that stem bark shows the presence of chemical constituents available in their extracts. The results of the foaming index of stem bark of $C$. deodara shows presence of saponins. The $\mathrm{pH}$ of the water extract of the samples for the stem bark showed that it is acidic in nature. Hence, through the organoleptic characteristics, the microscopic observations and observations of section cutting provides the basis for the identification and process of standardisation can be achieved.

\section{CONCLUSION}

The authenticity of the raw material was established based on organoleptic characteristics and microscopic observations obtained during study. The values of physicochemical parameter for stem bark showed the most of values obtained in present study was fairly comparable to the values obtained by different workers earlier. These values reveal that the stem bark shows the presence of chemical constituents available in their extracts. It suggests the possibility of some chemical inputs in stem bark which can be used as replacement of heart wood. The study lays the ground for combining the unique features for drug discovery and development.

\section{REFERENCES}

1. Bent, S., Ko, R. (2004) Commonly used herbal medicines in United States: A review. American journal of Medicinal Genetics, pp 116, 478.

2. Bose, A. De, K. \& Saroch, V. (2012). A Review on Latest Developments in the Standardization of Ayurvedic Drugs. International Journal of Pharmaceutical Research and Bioscience, 1(3), 96-119. 
3. Mukherjee, P.K. (2006). Quality control of herbal drugs an approach to evaluation of botanicals Business Horizons, Pharmaceutical publishers, New Delhi. (pp131-48, 183-422).

4. Khandelwal, K.R. (2006) Practical Pharmacognosy (16th ed. pp 9-14). Nirali Prakashan publication, New Delhi.

5. Kokate, C.K., Purohit, A.P. \& Gokhale, S. B. (2006) Textbook of Pharmacognosy (22nd ed. pp 593-597). Nirali Prakashan publication, New Delhi.

6. Johansen, D.A. (1940) Plant microtechnique (p 523). Mcgraw Hill Book Company Inc. New York, London.

7. Evans, W. C. (1996). Trecse and Evans Pharmacognosy (14th ed. p 194). Elsevier Publication, WB, Saunders Company Ltd. London.

8. WHO (2000) General guidelines for methodologies on research and evaluation of traditional medicine, (pp 173) World Health Organization, Geneva, $\mathrm{WHO} / \mathrm{EDM} / \mathrm{TRM} / 1$.

9. EMEA (2001) Note for guidance on quality of herbal medicinal products, European Agency for the Evaluation of Medicinal Products, EMEA/CVMP/814.
10. Indian Pharmacopoeia (1996), (vol 3 pp 47-49), Ministry of health and family welfare, Govt. of India, New Delhi.

11. WHO, (1998). Quality Control Methods for Medicinal Plant Materials. ISBN 9241545100 Retrieved from http://apps.who.int/iris/bitstream/10665/41986/924154 5100.pdf

\section{Source of Support: Nil \\ Conflict of Interest: None Declared}

How to cite this URL: Amrita Sharma \& Chander Shekhar Sharma: A Pharmacognostical Study On The Stem Bark Of Devadaru (Cedrus Deodara Roxb. Loud.). International Ayurvedic Medical Journal \{online\} 2020 \{cited November, 2020\} Available from: http://www.iamj.in/posts/images/upload/382_390.pdf 